\title{
COMMENTARY
}

\section{Endothelial $\mathrm{AT}_{2}$-receptors: chicken or egg?}

\author{
*,1Paul M. Vanhoutte
}

${ }^{1}$ Institut de Recherches Internationales Servier, 6 Place des Pléiades, 92415 Courbevoie, France

In this issue of the journal Katada \& Majima (2002) convincingly report that the activation of angiotensin II $\mathrm{AT}_{2}$-receptors on endothelial cells of perfused mesenteric arteries of the rat causes a dilatation, to which the local production of bradykinin and the resulting stimulation of kinin $\mathrm{B}_{2}$-receptors contribute greatly (Katada \& Majima, 2002). Earlier observations had demonstrated that disruption of the $\mathrm{AT}_{2}$ receptor gene leads to hypertension and hyperresponsiveness to the vasoconstrictor effects of angiotensin II (Ichiki et al., 1995; Hein et al., 1995; Siragy et al., 1999; Tanaka et al., 1999). That angiotensin II can lead to the production of bradykinin which in turn releases endothelium-derived relaxing factors has already been suggested (Wiemer et al., 1993; Seyedi et al., 1995; Jalowy et al., 1998; Gohlke et al., 1998; Liu et al., 1997; Henrion et al., 2001). However, Katada \& Majima, by the appropriate use of genetically kininogen-deficient rats and of inhibitors of kallikreins, as well as the measurement of the production of bradykinin, provide an elegant demonstration of the concept. Hence, their study reinforces considerably the observation that overexpression of $\mathrm{AT}_{2}$-receptors leads to an increased production of bradykinin (Tsutsumi et al., 1999). Taken in conjunction with the available information, the results of Katada \& Majima add significantly to the hypothesis that $\mathrm{AT}_{2}$-receptors contribute to the regulation of vasomotor tone, and thus of arterial blood pressure, by offsetting, in an endothelium-dependent, kinin-dependent fashion the vasoconstrictor properties of the powerful peptide angiotensin II.

Before jumping to the conclusion that a novel important physiological role for angiotensin II and the second subtype of its receptors has been discovered, the question, as always, has to be addressed: where would the angiotensin II come from? In the in vitro experiments reported by Katada \& Majima, angiotensin II was purchased and applied exogenously. In the in vivo situation, angiotensin II could reach the endothelial cells from the luminal side, presumably after transformation of circulating angiotensin I by converting enzyme conveniently located at the endothelial cell membrane. Alternatively, angiotensin II could be produced in the blood vessel wall itself through a local renin-angiotensin pathway and vascular chymases. In both cases, the activated peptide would switch on the local vascular kallikrein-kinin system, the existence of which has been established beyond doubt (Schmaier et al., 1988; 1999; Gardes et al., 1990; Oza et al., 1990; Van Iwaarden et al., 1998; Nolly et al., 1992; Mombouli \& Vanhoutte, 1991; 1992; Madeddu et al., 1993; Seyedi et al., 1995; Okamoto et al., 1998; Wolf et al., 1999;

*Author for correspondence; E-mail: vanhoutt@servier.fr
Yayama et al., 1998; Sakakibara et al., 1998; Sasaguri et al., 1999; Bergaya et al., 2001a; Dedio et al., 2001). The locally produced bradykinin in turn activates $\mathrm{B}_{2}$-kinin receptors on the endothelial cells leading to the release, towards the underlying vascular smooth muscle, of nitric oxide, endothelium-derived hyperpolarizing factor (EDHF) and prostacyclin (e.g. Cherry et al., 1982; Vanhoutte et al., 1993; Nakashima et al., 1993). The studies reported by Katada \& Majima do not really permit dissection of the relative contribution of those three endothelial mediators, as the authors only used indomethacin to block cyclooxygenases, but not inhibitors of NO synthase (to prevent the formation of nitric oxide) or the mixture apamin plus charybdotoxin (to inhibit that of EDHF). The relatively modest effect of even $10 \mu \mathrm{M}$ of indomethacin, and its independency of flow rate, imply that prostacyclin is not a major contributor to the response to angiotensin II. Indeed, at $10 \mu \mathrm{M}$, the question can be raised of the selectivity for cyclooxygenases of the effect(s) of indomethacin. Therefore, it may be premature to conclude, as Katada \& Majima do, that the release of bradykinin and prostacyclin occur in parallel, rather than in sequence.

If locally produced angiotensin II, through stimulation of $\mathrm{AT}_{2}$-receptors, activates the local vascular kallikrein-kinin system, as is strongly suggested by the experiments of Katada \& Majima, the next obvious question is what could set the generation of angiotensin II in motion? The answer may well come from another elegant study, reported so far in abstract form (Bergaya et al., 2001b). These authors, using wild type and kallikrein-gene knockout mice, demonstrate that $\mathrm{AT}_{2^{-}}$, but not $\mathrm{AT}_{1}$-receptors antagonists inhibit in part flowdependent dilatation in the wild type, an effect that is not observed in the knockout animals. $\mathrm{AT}_{2}$ and $\mathrm{B}_{2}$-kinin antagonists had a comparable, non-additive effect. Hence, the authors conclude that $\mathrm{AT}_{2}$-receptors contribute to the bradykinin-dependent component of the endothelium-dependent response to shear stress, which underlies flow-dependent dilatation. Their experiments thus indicate that angiotensin II and bradykinin act in sequence rather than synergistically, but do not permit to conclude which of the two peptides comes first in the chain of events following an increase in shear stress. In turn, the experiments by Katada \& Majima may provide the answer since they imply that the formation of angiotensin II must precede that of bradykinin. A role of $\mathrm{AT}_{2}$-receptors in flow-dependent vasodilatation has already been suggested (Matrougai et al., 1999). That locally produced bradykinin contributes to flow-dependent dilatation has been demonstrated not only in animal blood vessels, but also in the human coronary and peripheral circulation (Mombouli \& Vanhoutte, 1992; Groves et al., 1995; Hornig et al., 1997; Bergaya et al., 2001a; Meneton et al., 2001). 
Can the observations of Katada on Majima, truly be used to suggest a central role of $\mathrm{AT}_{2}$-receptor activation in flowdependent dilatation at this stage? Certainly, the effect of $\mathrm{AT}_{2}$ receptors is variable, and its importance seems of greater magnitude in the rat (Katada \& Majima, 2002) than in mice (Bergaya et al., 2001b) but the same can be argued, even in humans, for the bradykinin-dependent component of flowdependent vasodilatation that appears more pronounced in the coronary than in the femoral circulation (Groves et al., 1995; Hornig et al., 1997). If shear stress were to generate an ubiquitous production of vascular angiotensin II, one would expect $\mathrm{AT}_{1}$-antagonists to cause acute relaxations in perfused blood vessels, or to augment flow-dependent vasodilatation. This has not been observed so far (Mombouli \& Vanhoutte, 1991; Matrougui et al., 1999; Bergaya et al., 2001b). One should not exclude the possibility that endogenously produced bradykinin (the release of which increases with increased flow rates, as demonstrated by Katada \& Majima) and exogenously

\section{References}

BERGAYA, S., MENOTON, P., BLOCH-FAURE, M., MATTHIEU, E.C., ALHENC-GELAS, F., LEVY, B.I. \& BOULANGER, C.M. (2001a). Decreased flow-dependent dilation in carotid arteries of tissuekallikrein-knockout mice. Circ. Res., 88, 593-599.

BergayA, S., MENETON, P., BlOCH-FAURE, M., MATHiEU, E., ALHENC-GELAS, F., LEVY, B.I. \& BOULANGER, C.M. (2001b). Role of $\mathrm{AT}_{2}$ receptors in flow-induced dilation mediated by endogenous kinins. Circulation (suppl. II) 104 (17). (Poster, American Heart Association (AHA) Nov. 2001).

BOULANGER, C.M., CAPUTO, L. \& LEVY, B.I. (1995). Endothelial $\mathrm{AT}_{1}$-mediated release of nitric oxide decreases angiotensin II contractions in rat carotid artery. Hypertension, 26, $752-757$.

CAPUTO, L., BENESSIANO, J., BOULANGER, C.M. \& LEVY, B.I. (1995). Angiotensin II increases cGMP content via endothelial angiotensin II AT1 subtype receptors in the rat carotid artery. Arteroscl. Thromb. Vasc. Biol., 15, 1646-1651.

CHERRY, P.D., FURCHGOTT, R.F., ZAWADZKI, J.V. \& JOTHIANANDAN, D. (1982). Role of endothelial cells in relaxation of isolated arteries by bradykinin. Proc. Natl. Acad., 47, $221-228$.

DEDIO, J., WIEMER, G., RÜTTEN, H., DENDORFER, A., SCHÖLKENS, B.A., MÜLLER-ESTERL, W.I \& WOHLFART, P. (2001). Tissue kallikrein KLK1 is expressed de novo in endothelial cells and mediates relaxation of human umbilical veins. Biol. Chem., 382, $1483-1490$

GARDES, J., BAUSSANT, T., CORVOL, P., MENARD, J. \& ALHENCGELAS, F. (1990). Effect of bradykinin and kininogens in isolated rat kidney vasoconstricted by angiotensin II. Am. J. Physiol., 258, F1273-F1281.

GOHLKE, P., PEES, C. \& UNGER, T. (1998). AT 2 receptor stimulation increases aortic cyclic GMP in SHRSP by a kinin-dependent mechanism. Hypertension, 321, 349-355.

GROVES, P., KIRZ, S., HANJÜRG, J. \& DREXLER, H. (1995). Role of endogenous bradykinin in human coronary vasomotor control. Circulation, 92, 3424-3430.

HEIN, L., BARSH, G.S., PRATT, R.E., DZAU, V.J. \& KOBILKA, B.K. (1995). Behavioral and cardiovascular effects of disrupting the angiotensin II type-2 receptor gene in mice. Nature, 377, 744-747.

HENRION, D., KUBIS, N. \& LEVY, B.I. (2001). Physiological and pathophysiological functions of the $\mathrm{AT}_{2}$ subtype receptor of angiotensin II. From large arteries to the microcirculation. Hypertension, 38, $1150-1157$.

HORNIG, B., KOHLER, C. \& DREXLER, H. (1997). Role of bradykinin in mediating vascular effects of angiotensin-converting enzyme inhibitors in humans. Circulation, 95, 1115-1118.

ICHIKI, T., LABOSKY, P.A., SHIOTA, C., OKUYAMA, S., IMAGAWA, Y., FOGO, A., NIIMURA, F., ICHIKAWA, I., HOGAN, B.L.M. \& INAGAMI. (1995). Effects on blood pressure and exploratory behavior of mice lacking angiotensin II type- 2 receptor. Nature, 377, $748-750$. added angiotensin II may interact with a common binding site on the endothelial cells, that shares pharmacological properties with both $\mathrm{AT}_{2}$ and $\mathrm{B}_{2}$-kinin receptors. After all, the two peptides also share common binding sites on converting enzyme. Such common binding site could be upregulated by shear stress, or modulated in an allosteric fashion by occupancy of the $\mathrm{AT}_{1}$-receptors. Alternatively if endothelial cells are endowed with both $\mathrm{AT}_{1}$ and $\mathrm{AT}_{2}$ receptors, the occupancy of the $\mathrm{AT}_{1}$-side may be required before the $\mathrm{AT}_{2}$-activation can result in release of endothelial mediators, which would explain why high concentration of angiotensin II increase the production of nitric oxide (Boulanger et al., 1995; Caputo et al., 1995). Whatever the cellular mechanism involved, the findings of Katada \& Majima throw a new light on the pharmacology of angiotensin II $\mathrm{AT}_{1}$-receptor blockers, and if they can be extrapolated to the human vasculature, may help to understand why these drugs share many pharmacological and therapeutic properties with converting enzyme inhibitors.
JALOWY, A., SCHULZ, R., DÖRGE, H., BEHRENDS, M. \& HEUSCH, G. (1998). Infarct size reduction by $\mathrm{AT}_{1}$-receptor blockade through a signal cascade of $\mathrm{AT}_{2}$-receptor activation, bradykinin and prostaglandins in pigs. J. Am. Coll. Cardiol., 32, 1787-1796.

KATADA, J. \& MAJIMA, M. (2002). $\mathrm{AT}_{2}$ receptor-dependent vasodilation is mediated by activation of vascular kinin generation under flow conditions. Br. J. Pharmacol., 136, $484-$ 491.

LIU, Y.H., YANG, X.P., SHAROV, V.G., NASS, O., SABBAH, H.N., PETERSON, E. \& CARRETERO, O.A. (1997). Effects of angiotensin-converting enzyme inhibitors and angiotensin II type 1 receptor antagonists in rats with heart failure. Role of kinins and angiotensin II type 2 receptors. J. Clin. Invest., 99, $1926-$ 1935.

MADEDDU, P., GHERLI, T., BACCIU, P.P., MAIOLI, M. \& GLORIOSO, N. (1993). A kallikrein-like enzyme in human vascular tissue. Am. J. Hypertens., 6, 344-348.

Meneton, P., Bloch-FAure, M., HAgege, A., RUETTEN, H., HUANG, W., BERGAYA, S., CEILER, D., GEHRING, D., MARTINS, I., SALMON, G., BOULANGER, C.M., NUSSBERGER, J., CROZATIER, B., GASC, J.M., HEUDES, D., BRUNEVAL, P., DOESTCHMAN, M., MENARD, J. \& ALHENC-GELAS, F. (2001). Cardiovascular abnormalities with normal blood pressure in tissue kallikrein-deficient mice. Proc. Natl. Acad. Sci. U.S.A., 98, $2634-2639$

MATROUGAI, K., LOUFRANI, L., HEYMES, C., LEVY, B.I. \& HENRION, D. (1999). Activation of AT2 receptors by endogenous angiotensin II is involved in flow-induced dilatation in rat resistance arteries. Hypertension, 34, 659-665.

MOMBOULI, J.V. \& VANHOUTTE, P.M. (1991). Kinins and endothelium-dependent relaxations to converting enzyme inhibitors in perfused canine arteries. J. Cardiovascular Pharmacol. 18, $926-927$

MOMBOUli, J.V. \& VANHOUTTE, P.M. (1992). Kinins mediate kallikrein-induced endothelium-dependent relaxations in isolated canine coronary arteries. Biochem. Biophys. Res. Comm., 185, 693-697.

NAKASHIMA, M., MOMBOULI, J.V., TAYLOR, A.A. \& VANHOUTTE, P.M. (1993). Endothelium-dependent hyperpolarization caused by bradykinin in human coronary arteries. J. Clin. Invest., 92, $2867-2871$.

NOlly, H., LAMA, M., CARRETERO, O. \& SCICli, A. (1992). The kallikrein-kinin system in blood vessels. Agents Actions, 38 (suppl 3), $1-9$.

OKAMOTO, H., YAYAMA, K., SHIBATA, H., NAGAOKA, M. \& TAKANO, M. (1998). Kininogen expression by rat vascular smooth muscle cells: Stimulation by lipopolysaccharide and angiotensin II. Biochim. Biophys. Acta, 1404, $329-337$. 
OZA, N.B., SCHWARTZ, J.H., GOUD, H.D. \& LEVINSKY, G.G. (1990) Rat aortic smooth muscle cells in culture express kallikrein, kinninogen, and bradykininase activity. J. Clin. Invest., 85, 597 600 .

SAKAKIBARA, T., HINTZE, T.H. \& NASJELETTI, A (1998). Determinants of kinin release in isolated rat hindquarters. Am. J. Physiol., 43, R120-R125.

SASAGURI, M., NODA, K. \& TSUJI, E. (1999). Structure of a kalikrein-like enzyme and its tissue localization in the dog. Immunopharmacol., 44, 15-19.

SCHMAIER, A.H., KUO, A., LUNDBERG, D., MURRAY, S. \& CINES, D.B. (1988). The expression of high molecular weight kininogen on human umbilical vein endothelial cells. J. Biol. Chem., 263, $16327-16333$

SCHMAIER, A.H., RØJKAER, R. \& SHARIAT-MADA, Z. (1999). Activation of the plasma kallikrein/kinin system on cells: a revised hypothesis. Thromb. Hemostat., 82, 226-233.

SEYEDI, N., XU, X., NASJLETTI, A. \& HINTZE, T.H. (1995). Coronary kinin generation mediates nitric oxide release after angiotensin receptor stimulation. Hypertension, 26, $164-170$.

SIRAGY, H.M., INAGAMI, T., ICHIKI, T. \& CAREY, R.M. (1999). Sustained hypersensitivity to angiotensin II and its mechanism in mice lacking the subtype-2 $\left(\mathrm{AT}_{2}\right)$ angiotensin receptor. Proc. Natl. Acad. Sci. U.S.A., 96, 6506-6510.

TANAKA, M., TSUCHIDA, S., IMAI, T., FUJI, N., MIYAZAKI, H., ICHIKI, T., NARUSE, M. \& INAGAMI, T. (1999). Vascular response to angiotensin II is exaggerated through an upregulation of AT1 receptor in AT2 knockout mice. Biochem. Biophys. Res. Commun., 258, $194-198$.
TSUTSUMI, Y., MATSUBARA, H., MASAKI, H., KURIHARA, H., MURASAWA, S., TAKAI, S., MIYAZAKI, M., NOZAWA, Y., OZONO, R., NAKAGAWA, K., MIWA, T., KAWADA, N., MORI, Y., SHIBASAKI, Y., TANAKA, Y., FUJIYAMA, S., KOYAMA, Y., FUJIYAMA, A., TAKAHASHI, H. \& IWASAKA, T. (1999). Angiotensin II type 2 receptor overexpression activates the vascular kinin system and causes vasodilatation. J. Clin. Invest., 104, $925-935$

VANHOUTTE, P.M., BOULANGER, C.M., ILliANO, S.C., NAGAO, T., VIDAL, M. \& MOMBOULI, J.V. (1993). Endothelium-dependent effects of converting-enzyme inhibitors. J. Cardiovasc. Pharmacol., 22 (suppl 5), S10-S16.

VAN IWAARDEN, F., DE GROOT, P.G. \& BOUMA, B.N. (1998). The binding of high molecular weight kininogen to cultured human endothelial cells. J. Biol. Chem., 263, $4698-4703$.

WIEMER, G., SCHOLKENS, B.A., BUSSE, R., WAGNER, A., HEITSCH, H. \& LINZ, W. (1993). The functional role of angiotensin II subtype $\mathrm{AT}_{2}$-receptors in endothelial cells and isolated ischemic rat hearts. Pharm. Pharmacol. Lett., 3, 24-27.

WOLF, W.C., HARLEY, R.A., SLUCE, D., CHAO, L. \& CHAO, J. (1999). Localization and expression of tissue kallikrein and kallistatin in human blood vessels. J. Histochem. Cytochem., 47, $221-228$.

YAYAMA, K., KIROKI, S., MASAOKI, T. \& HIROSHI, O. (1998). Expression of Low-Molecular-Weight kininogen in mouse vascular smooth muscle. Cell. Biol. PharmBull., 21, $772-774$.

(Received April 8, 2002 Accepted April 17, 2002) 